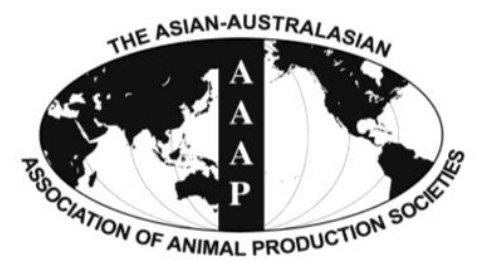

Asian-Aust. J. Anim. Sci.

Vol. 26, No. 2 : 233-240 February 2013

http://dx.doi.org/10.5713/ajas.2012.12407

www.ajas.info

pISSN 101 1-2367 elSSN 1976-5517

\title{
Effects of Dietary L-carnitine Supplementation on Growth Performance, Organ Weight, Biochemical Parameters and Ascites Susceptibility in Broilers Reared Under Low-temperature Environment
}

\author{
Y. W. Wang, D. Ning, Y. Z. Peng and Y. M. Guo* \\ State Key Lab of Animal Nutrition, College of Animal Science and Technology, \\ China Agricultural University, Beijing 100193, China
}

\begin{abstract}
The objective of this study was to investigate the effects of L-carnitine on growth performance, organ weight, biochemical parameters of blood, heart and liver, and ascites susceptibility of broilers at different ages reared under a low-temperature environment. A total of 4201 -d-old male Ross 308 broilers were randomly assigned to two dietary treatments with fifteen replicates of fourteen broilers each. Treatment diets consisted of L-carnitine supplementation at levels of 0 and $100 \mathrm{mg} / \mathrm{kg}$. At 11-d of age, low temperature stress was used to increase ascites susceptibility. Blood, heart and liver samples were collected at different ages for analysis of boichemical parameters. The results showed that, there was no significant difference in growth performance with L-carnitine supplementation, but the mortality due to ascites was significantly decreased. Dietary L-carnitine supplementation significantly reduced heart index (HI) and ascites heart index (AHI) on d 21, lung index (LUI) on d 35 and liver index (LI) on d 42. The broilers fed diets containing L-carnitine had significantly lower red blood cell counts (RBC), hemoglobin (HGB) concentration and hematocrit (HCT) on d 42. Dietary L-carnitine supplementation significantly reduced malondialdehyde (MDA) content of heart tissue on d 21 and 35 , and significantly increased total superoxide dismutase (T-SOD) and Glutathione peroxidase (GSH-Px) activity of the heart on d 21 and 42. L-carnitine supplementation significantly reduced serum triglyceride (TG) content on d 28 and 35 and serum glucose (GLU) on d 35 and 42, and significantly increased serum total protein (TP) and globulin (GLO) content on d 42. L-carnitine supplementation significantly enhanced liver succinodehydrogenase (SDH), malic dehydrogenase (MDH) and $\mathrm{Na}^{+}-\mathrm{K}^{+}$-ATPase activity on $\mathrm{d} 28$, and tended to reduce the lactic acid (LD) level of liver on $\mathrm{d} 35(\mathrm{p}=0.06)$. L-carnitine supplementation significantly reduced serum uric acid (UA) content on d 28, 35 and 42. Based on the current results, it can be concluded that dietary L-carnitine supplementation reduced organ index, red blood cell counts and hematocrit, enhanced antioxidative capacity of the heart, enhanced liver enzymes activity involved in tricarboxylic acid cycle, and reduced serum glucose and triglyceride. Therefore, it is suggested that L-carnitine can potentially reduce susceptibility and mortality due to ascites. (Key Words: Antioxidant Enzyme, Ascites, Broiler, L-carnitine)
\end{abstract}

\section{INTRODUCTION}

Ascites syndrome is a serious metabolic disease and is still a problem for the chicken industry in the various parts of world. Although the incidence of this metabolic disorder in well-managed flocks is very low, it causes important economic losses to the poultry breeding industry (Maxwell and Robertson, 1997). It is estimated that $5 \%$ of broilers and $20 \%$ of roaster birds die of ascites (Balog, 2003), so it is evident that the economic losses due to ascites are significant. Genetic, physiological, environmental, and management factors all seem to interact to produce a

\footnotetext{
* Corresponding Author: Y. M. Guo. Tel: +86-10-6273-3900, Fax: +86-10-6273-3900, E-mail: guoyum@cau.edu.cn Submitted Jul. 31, 2012; Accepted Sept. 28, 2012; Revised Oct. 5, 2012
}

cascade of events that culminate in ascites syndrome (Baghbanzadeh and Decuypere, 2008). Many reports on the relationship between nutrition and ascites indicated that dietary supplemented with nutrition regulatory agents such as vitamin E (Bottje et al., 1997; Villar-Patino et al., 2002), L-arginine (Lorenzoni et al., 2006; Tan et al., 2007), or Lcarnitine (Buyse et al., 2001; Geng et al., 2004) can reduce the incidence of ascites.

The major metabolic role of L-carnitine appears to be the transport of long-chain fatty acids into the mitochondria for $\beta$-oxidation and energy production. It is generally accepted that endogenous L-carnitine synthesis together with its dietary intake should be sufficient for normal function. However, in cases of increased metabolic rate (in fasting-growth broilers and cold temperature) when energy 
demands are elevated, the availability of L-carnitine may become a limiting factor for oxidative metabolism. Olkowski et al. (2007) reported that the L-carnitine level of heart in broilers with heart failure was lower than in normal broilers. In these circumstances, additional exogenous L-carnitine might prove beneficial.

It is reported that the elevated production of reactive oxygen species in broilers prone to ascites may potentiate the development of ascites or aggravate ascites as it occurs (Enkvetchakul et al., 1993; Bottje and Wideman, 1995; Arab et al., 2006). Previous studies in our laboratory reported that diets supplemented with L-carnitine can improve liver antioxidative capacity and reduced the mortality due to ascites (Geng et al., 2004). These effects might be attributed to its free radical scavenging properties. Buyse et al. (2001) reported that L-carnitine supplementation significantly reduced plasma glucose concentrations on d 17, which suggested that liver energy metabolic state was altered. Whether L-carnitine can reduce the incidence of ascites by improving heart antioxidative capacity or the liver energy metabolism state needs further investigation.

Cold temperature can increase ascites susceptibility by increasing both metabolic oxygen requirements and pulmonary hypertension (Stolz et al., 1992). However, at present, there is little information about the changes of physiological parameters such as fasting blood glucose, serum protein, triglyceride (Zhang et al., 2010; Kheiri et al., 2011), heart antioxidative capacity and liver metabolic enzymes activities of broilers grown under a low temperature environment (Yersin et al., 1992; Biswas et al., 1995; Diaz-Cruz et al., 1996).

Therefore, this study was conducted to investigate the effects of dietary L-carnitine supplementation on growth performance, biochemical parameters of blood, heart, and liver tissue, and ascites susceptibility of broilers grown under a low-temperature regime.

\section{MATERIALS AND METHODS}

\section{Animal and diets}

At $1 \mathrm{~d}$ of age, 420 male broiler chickens (Ross-308) were randomly assigned to two dietary treatments, each with fifteen replicates of 14 broilers. The initial body weight was $(50.22 \pm 0.69) \mathrm{g}$. Treatment consisted of feeding starter (d 1 to 21 ) and grower (d 22 to 42) diets with 0 and $100 \mathrm{mg} / \mathrm{kg} \mathrm{L}$-carnitine (Table 1). Diets, in pellet form, were formulated to meet or exceed all nutrient requirements (NRC, 1994).

\section{Animal management}

Birds were reared in cages $(2.4 \times 0.6 \times 0.6 \mathrm{~m})$ with a screen wired floor. The temperature in the house was 32 to
Table 1. Composition of experimental diets

\begin{tabular}{lrr}
\hline Item & $\mathrm{d} \mathrm{1-21}$ & $\mathrm{d} 22-42$ \\
\hline Ingredient & & \\
Corn & 50.44 & 59.40 \\
Soybean meal (45\%) & 27.88 & 22.00 \\
Corn gluten meal (58\%) & 12.00 & 11.03 \\
Soybean oil & 5.03 & 3.57 \\
Dicalcium phosphate & 1.89 & 1.42 \\
Limestone & 1.25 & 1.31 \\
Salt & 0.50 & 0.50 \\
Mineral premix & 0.20 & 0.20 \\
Vitamin premix & 0.03 & 0.02 \\
Choline chloride $(50 \%)$ & 0.10 & 0.16 \\
Aureomycin (15\%) & 0.10 & 0.10 \\
Ethoxyquin (33\%) & 0.03 & 0.03 \\
L-lysine & 0.45 & 0.24 \\
DL-methionine & 0.10 & 0.02 \\
Total & 100.00 & 100.00 \\
Nutrient composition & & \\
ME (Mcal/kg) & 3.20 & 3.20 \\
CP (\%) & 22.70 & 19.50 \\
Ca (\%) & 0.98 & 0.88 \\
Total phosphorus $(\%)$ & 0.64 & 0.54 \\
Available P (\%) & 0.45 & 0.35 \\
Lysine (\%) & 1.25 & 1.00 \\
Methionine (\%) & 0.50 & 0.38 \\
\hline Suppied & & \\
\end{tabular}

${ }^{a}$ Supplied the following per kg complete diet: $\mathrm{Cu}, 8 \mathrm{mg} ; \mathrm{Zn}, 75 \mathrm{mg}$; Fe, $80 \mathrm{mg}$; Mn, $100 \mathrm{mg}$; Se, $0.15 \mathrm{mg}$; I, $0.35 \mathrm{mg}$;

${ }^{\mathrm{b}}$ Supplied the following (per kg complete diet): vitamin A, 12,500 IU; vitamin $\mathrm{D}_{3}$, 2,500 IU; vitamin E, $30 \mathrm{IU}$; vitamin $\mathrm{K}_{3}, 2.65 \mathrm{mg}$; thiamine, 2 $\mathrm{mg}$; riboflavin, $6 \mathrm{mg}$; vitamin $\mathrm{B}_{12}, 0.025 \mathrm{mg}$; biotin, $0.0325 \mathrm{mg}$; folic acid, $1.25 \mathrm{mg}$; pantothenic acid, $12 \mathrm{mg}$; niacin, $50 \mathrm{mg}$.

$35^{\circ} \mathrm{C}$ in the first week, and was lowered by $1^{\circ} \mathrm{C}$ every other day till $30^{\circ} \mathrm{C}$ on $\mathrm{d} 10$. From d 11 , all birds were exposed to a temperature cycle of $17^{\circ} \mathrm{C}$ during the daytime and $14^{\circ} \mathrm{C}$ at night in order to increase ascites susceptibility until the end of the experiment (42 d). The broilers had free access to feed and water with $23 \mathrm{~h}$ fluorescent illumination per day throughout the trial period. The broilers were vaccinated with ND-IB vaccine at 7 and $21 \mathrm{~d}$ age, and IBD vaccine at 14 and $28 \mathrm{~d}$ age.

All birds that died were examined to determine if the cause was ascites. The following symptoms were used to diagnosis ascites: i) right ventricle hypertrophy and cardiac muscle laxation, ii) swollen and stiff liver, iii) and clear, yellowish and colloid fluid appearance in the pericardium or abdominal cavity (Baghbanzadeh et al., 2008).

The study protocol was approved and conducted in accordance with the Animal Ethics Committee Guidelines of China Agricultural University.

\section{Sampling and measurement}

Performance determination: On d 21 and 42, average 
Table 2. Effects of dietary L-carnitine supplementation on broiler growth performance and mortality ${ }^{\mathrm{a}}$

\begin{tabular}{|c|c|c|c|c|c|c|c|c|c|c|}
\hline \multirow{2}{*}{$\begin{array}{l}\text { L-carnitine } \\
(\mathrm{mg} / \mathrm{kg})\end{array}$} & \multicolumn{2}{|c|}{$\begin{array}{c}\text { ADG } \\
\left(\mathrm{g} \mathrm{bird}^{-1} \mathrm{~d}^{-1}\right)\end{array}$} & \multicolumn{2}{|c|}{$\begin{array}{c}\text { AFI } \\
\left(\mathrm{g} \mathrm{bird}^{-1} \mathrm{~d}^{-1}\right)\end{array}$} & \multicolumn{2}{|c|}{$\begin{array}{c}\mathrm{ABW} \\
\left(\mathrm{g} \mathrm{bird}^{-1}\right)\end{array}$} & \multicolumn{2}{|c|}{ FCR } & \multicolumn{2}{|c|}{$\begin{array}{c}\text { Mortality } \\
(\%)\end{array}$} \\
\hline & D 1 to 21 & D 22 to 42 & D 1 to 21 & D 22 to 42 & D 21 & D 42 & D 1 to 21 & D 1 to 42 & Total & Ascites \\
\hline 0 & 38.8 & 68.4 & 63.5 & $165 * *$ & 847 & 2,408 & 1.64 & 2.09 & $11.8 *$ & $10.2 *$ \\
\hline 100 & 38.8 & 61.3 & 63.2 & 137 & 855 & 2,393 & 1.61 & 2.07 & 7.84 & 5.88 \\
\hline Pool SEM & 0.23 & 2.44 & 0.57 & 5.51 & 3.28 & 37.1 & 0.01 & 0.04 & 1.51 & 1.42 \\
\hline p-value & NS & NS & NS & 0.006 & NS & NS & NS & NS & 0.044 & 0.037 \\
\hline
\end{tabular}

$\mathrm{ADG}=$ Average daily gain, $\mathrm{AFI}=$ Average feed intake, $\mathrm{ABW}=$ Average body weight, $\mathrm{FCR}=$ Feed conversation ratio (expressed as $\mathrm{kg}$ of feed: $\mathrm{kg}$ of weight gain), $\mathrm{SEM}=$ Standard error of mean .

${ }^{a}$ Each value is the mean of 15 replicates of 14 birds each. NS $=$ Not significant, $* p<0.05$ and $* * p<0.01$.

daily gain (ADG), average feed intake (AFI), average body weight $(\mathrm{ABW})$ and feed conversion ratio (feed intake:BW gain, FCR) were determined on pen basis, and the mortality due to ascites was calculated.

Blood parameters and blood biochemical parameters: On d 21, 28, 35 and 42, one bird was randomly selected from each pen, and body weight was weighted after $8 \mathrm{~h}$ of feed deprivation. Whole blood samples were collected by venipuncture into EDTA-K $\mathrm{K}_{3}$ anticoagulation tubes for measuring red blood cell counts (RBC), hemoglobin (HGB), hematocrit (HCT) (Sysmex KX-21N Automatic blood analyzer, Japan). Another set of blood samples were immediately collected into non-anticoagulant tubes to obtain serum for fasting blood glucose (GLU), serum total protein (TP), albumin (ALB), globulin (GLO), triglyceride (TG), uric acid (UA) determination (Unicel DXC 800, Beckman Coulter) (Wang et al., 2012).

Organ index and ascites heart index: After collecting blood samples, the birds were killed by jugular bleeding. Heart, lung, liver, right ventricle (RV) and total ventricle (TV) were weighed to calculate liver index (LI), lung index (LUI), heart index (HI) and ascites heart index (AHI). LI, LUI, and HI were calculated as the (organ weight/body weight $) \times 100$, and AHI was calculated as the $(\mathrm{RV} / \mathrm{TV})$ (Julian et al., 1993).

Heart antioxidative capacity and liver energy metabolic parameters: Heart and liver tissue were isolated and immediately put into liquid nitrogen, then heart or liver tissue were minced and homogenized (10\%, wt/vol) in physiological saline water at $4^{\circ} \mathrm{C}$, then centrifuged at 3,500 $\mathrm{g}$ for $15 \mathrm{~min}$ at $4^{\circ} \mathrm{C}$, and the supernatant was collected and stored in $-30^{\circ} \mathrm{C}$ for further analysis. Malonaldehyde (MDA) content was determined with the method of thibabituric acid (TBA). Total superoxide dismutase (T-SOD) activity, glutathione peroxidase (GSH-Px) activity, and total antioxidative capability (T-AOC) in heart tissue; hexokinase (HK), succinodehydrogenase ( $\mathrm{SDH})$, malic dehydrogenase $(\mathrm{MDH}), \mathrm{Na}^{+}-\mathrm{K}^{+}$-ATPase activity and pyruvic acid (PD), lactic acid (LD) concentration in liver tissue were measured using a commercially available colorimetric diagnostic kit (Nanjing jiancheng Bioengineering Institute, Nanjing,
China; Tan et al., 2010). The protein content of heart and liver tissue were measured by Coomassie Brilliant Blue G-250 reagent with bovine serum albumin as a standard.

\section{Statistical analysis}

Data were presented as Mean. The statistical analysis was performed with SPSS 16.0 software for Windows. Independent sample T-test was used and a probability level of $\mathrm{p} \leq 0.05$ was considered statistically significant. The pen average was used as the experimental unit. Mortality due to ascites was calculated on pen basis and analyzed after arcsin transformation.

\section{RESULTS}

The effects of L-carnitine on ABW, FCR and mortality due to ascites are shown in Table 2. ADG of broilers on $\mathrm{d} 1$ to 21 and d 21 to 42 , and AFI on d 1 to 21 were not influenced by L-carnitine supplementation, but AFI on d 21 to 42 was significantly reduced by dietary L-carnitine supplementation. Both $\mathrm{ABW}$ and FCR were not influenced by L-carnitine supplementation in broilers during 0 to $3 \mathrm{wk}$ and 3 to $6 \mathrm{wk}$, but mortality due to ascites (especially during wk 4 to wk 6) was significantly reduced.

As shown in Table 3, dietary L-carnitine supplementation significantly decreased $\mathrm{HI}$ and AHI on $\mathrm{d}$ 21, LUI on d 35, and LI on d 35.

As shown in Table 3, the broilers fed with diets supplemented with L-carnitine had significantly lower RBC, HGB and HCT than those fed the control diet on $\mathrm{d} 42$, and tended to have lower HGB $(p=0.065)$ and HCT $(p=0.076)$ on d 21. L-carnitine did not influence RBC, HGB and HCT were not influenced by L-carnitine supplementation on d 28 and 35 .

The results of heart antioxidative capacity are shown in Table 4. Dietary L-carnitine supplementation significantly reduced MDA concentration of heart tissue on d 21 and 35, and significantly increased T-SOD and GSH-Px activity of heart tissue on $\mathrm{d} 21$ and 42 .

The results of liver energy metabolic enzymes activity are shown in Table 5. Liver hexokinase activity on d 28 was 
Table 3. Effects of dietary L-carnitine supplementation on broiler organ index and blood parameters ${ }^{\mathrm{a}}$

\begin{tabular}{|c|c|c|c|c|c|c|c|}
\hline $\begin{array}{l}\text { L-carnitine } \\
(\mathrm{mg} / \mathrm{kg})\end{array}$ & $\mathrm{LI}(\%)$ & LUI (\%) & $\mathrm{HI}(\%)$ & AHI & $\operatorname{RBC}\left(10^{12} / \mathrm{L}\right)$ & HGB $(g / L)$ & HCT \\
\hline \multicolumn{8}{|l|}{ D 21} \\
\hline 0 & 2.81 & 0.47 & $0.66 *$ & $0.21 * *$ & 2.96 & 125 & 0.39 \\
\hline 100 & 2.73 & 0.45 & 0.61 & 0.19 & 2.78 & 116 & 0.36 \\
\hline Pool SEM & 0.034 & 0.009 & 0.009 & 0.004 & 0.055 & 2.51 & 0.007 \\
\hline p-value & NS & NS & 0.013 & 0.003 & NS & 0.065 & 0.076 \\
\hline \multicolumn{8}{|l|}{ D 28} \\
\hline 0 & 2.62 & 0.21 & 0.59 & 0.21 & 2.62 & 111 & 0.35 \\
\hline 100 & 2.67 & 0.22 & 0.60 & 0.22 & 2.64 & 115 & 0.36 \\
\hline Pool SEM & 0.055 & 0.007 & 0.012 & 0.008 & 0.034 & 1.59 & 0.005 \\
\hline p-value & NS & NS & NS & NS & NS & NS & NS \\
\hline \multicolumn{8}{|l|}{ D 35} \\
\hline 0 & 2.62 & $0.55 * *$ & 0.58 & 0.22 & 2.79 & 112 & 0.35 \\
\hline 100 & 2.56 & 0.41 & 0.55 & 0.22 & 2.87 & 114 & 0.35 \\
\hline Pool SEM & 0.032 & 0.023 & 0.011 & 0.003 & 0.037 & 1.48 & 0.004 \\
\hline p-value & NS & 0.000 & NS & NS & NS & NS & NS \\
\hline \multicolumn{8}{|l|}{ D 42} \\
\hline 0 & $2.58 * *$ & 0.19 & 0.53 & 0.25 & $3.00 *$ & $106^{* *}$ & $0.40 * *$ \\
\hline 100 & 2.25 & 0.21 & 0.53 & 0.25 & 2.79 & 95 & 0.35 \\
\hline Pool SEM & 0.066 & 0.005 & 0.011 & 0.011 & 0.059 & 2.14 & 0.009 \\
\hline p-value & 0.004 & NS & NS & NS & 0.050 & 0.001 & 0.001 \\
\hline
\end{tabular}

LI = Liver index, LUI = Lung index, HI = Heart index, AHI = Ascites heart index, RBC = Red blood cells, HGB = Haemoglobin, and HCT = Hematocrit.

${ }^{\text {a }}$ Each value is the mean of 15 replicate group of one bird each, and the same as Table 3 to 6 .

NS $=$ Not significant, $* \mathrm{p}<0.05$ and $* * \mathrm{p}<0.01$

Table 4. Effects of dietary L-carnitine supplementation on heart antioxidative capacity

\begin{tabular}{|c|c|c|c|c|}
\hline $\begin{array}{l}\text { L-carnitine } \\
(\mathrm{mg} / \mathrm{kg})\end{array}$ & $\begin{array}{c}\text { MDA } \\
\mathrm{nmol} / \mathrm{mg} \text { protein }\end{array}$ & $\begin{array}{c}\text { GSH-Px } \\
\text { U/mg protein }\end{array}$ & $\begin{array}{c}\text { T-SOD } \\
\text { U/mg protein }\end{array}$ & $\begin{array}{c}\text { T-AOC } \\
\text { U/mg protein }\end{array}$ \\
\hline \multicolumn{5}{|l|}{ D 21} \\
\hline 0 & $0.89 * *$ & 31.1 & 130 & 0.30 \\
\hline 100 & 0.63 & $44.7 *$ & $156 *$ & $0.35 *$ \\
\hline Pool SEM & 0.046 & 2.98 & 5.79 & 0.012 \\
\hline p-value & 0.001 & 0.011 & 0.019 & 0.041 \\
\hline \multicolumn{5}{|l|}{ D 28} \\
\hline 0 & 0.77 & 38.7 & 120 & 0.32 \\
\hline 100 & 0.68 & 38.2 & 133 & 0.38 \\
\hline Pool SEM & 0.029 & 0.645 & 5.48 & 0.04 \\
\hline p-value & NS & NS & NS & NS \\
\hline \multicolumn{5}{|l|}{ D 35} \\
\hline 0 & $0.88 *$ & 39.8 & 156 & 0.43 \\
\hline 100 & 0.73 & 35.6 & 162 & 0.45 \\
\hline Pool SEM & 0.02 & 0.59 & 3.06 & 0.05 \\
\hline p-value & 0.046 & NS & NS & NS \\
\hline \multicolumn{5}{|l|}{ D 42} \\
\hline 0 & 0.76 & 32.9 & 164 & 0.60 \\
\hline 100 & 0.77 & $39.7 *$ & $184 *$ & 0.62 \\
\hline Pool SEM & 0.021 & 1.24 & 4.21 & 0.05 \\
\hline p-value & NS & 0.032 & 0.047 & NS \\
\hline
\end{tabular}

MDA = Malondialdehyde, GSH-Px = Glutathione peroxidase, T-SOD = Total superoxide dismutase, and T-AOC = Total antioxidant capacity.

NS $=$ Not significant, $* \mathrm{p}<0.05$ and $* * \mathrm{p}<0.01$ 
Table 5. Effect of dietary L-carnitine supplementation on liver energy metabolic parameters

\begin{tabular}{|c|c|c|c|c|c|c|}
\hline $\begin{array}{l}\text { L-carnitine } \\
\text { (mg/kg) }\end{array}$ & $\begin{array}{c}\mathrm{HK} \\
\mathrm{U} / \mathrm{mg} \text { protein }\end{array}$ & $\begin{array}{c}\mathrm{SDH} \\
\mathrm{U} / \mathrm{mg} \text { protein }\end{array}$ & $\begin{array}{c}\mathrm{MDH} \\
\mathrm{U} / \mathrm{mg} \text { protein }\end{array}$ & $\begin{array}{c}\mathrm{Na}^{+}-\mathrm{K}^{+} \text {-ATPase } \\
\mu \mathrm{molPi} / \mathrm{mg} \text { protein } / \mathrm{h}\end{array}$ & $\begin{array}{c}\mathrm{PD} \\
\mathrm{mmol} / \mathrm{mg} \text { protein }\end{array}$ & $\begin{array}{c}\mathrm{LD} \\
\mathrm{mmol} / \mathrm{mg} \text { protein }\end{array}$ \\
\hline \multicolumn{7}{|l|}{ D 21} \\
\hline 0 & 29.7 & 2.66 & 13.5 & 2.05 & 0.018 & 0.48 \\
\hline 100 & 31.9 & 3.12 & 12.9 & 2.86 & 0.013 & 0.45 \\
\hline Pool SEM & 2.79 & 0.25 & 0.25 & 0.217 & 0.003 & 0.022 \\
\hline p-value & NS & NS & NS & 0.055 & NS & NS \\
\hline \multicolumn{7}{|l|}{ D 28} \\
\hline 0 & 29.9 & 3.83 & 12.5 & 2.43 & 0.007 & 0.43 \\
\hline 100 & 39.8 & $5.75 *$ & $13.9 *$ & $2.81 *$ & 0.012 & 0.40 \\
\hline Pool SEM & 3.13 & 0.53 & 0.38 & 0.043 & 0.002 & 0.015 \\
\hline p-value & 0.071 & 0.016 & 0.050 & 0.041 & NS & NS \\
\hline \multicolumn{7}{|l|}{ D 35} \\
\hline 0 & 27.1 & 2.66 & 11.3 & 2.52 & 0.007 & 0.54 \\
\hline 100 & 36.3 & 3.24 & 12.0 & $2.97 *$ & 0.011 & 0.48 \\
\hline Pool SEM & 2.31 & 0.25 & 0.33 & 0.447 & 0.001 & 0.022 \\
\hline p-value & NS & NS & NS & 0.044 & NS & 0.061 \\
\hline \multicolumn{7}{|l|}{ D 42} \\
\hline 0 & 27.8 & 5.09 & 8.70 & 1.91 & 0.008 & 0.43 \\
\hline 100 & 38.5 & 6.31 & 8.98 & 2.05 & 0.011 & 0.30 \\
\hline Pool SEM & 3.64 & 0.76 & 0.30 & 0.072 & 0.001 & 0.038 \\
\hline p-value & NS & NS & NS & NS & NS & NS \\
\hline
\end{tabular}

HK = Hexokinase, $\mathrm{SDH}=$ Succinodehydrogenase, $\mathrm{MDH}=$ Malic dehydrogenase, $\mathrm{PD}=$ Pyruvic acid, and LD = Lactic acid.

NS $=$ Not significant, $* \mathrm{p}<0.05$.

numerically, but not significantly increased by L-carnitine concentration of LD of liver on d $35(\mathrm{p}=0.061)$.

supplementation $(\mathrm{p}=0.071)$. L-carnitine supplementation As shown in Table 6, L-carnitine supplementation significantly enhanced the activity of liver SDH, MDH and significantly reduced serum TG concentration on d 28 and $\mathrm{Na}^{+}-\mathrm{K}^{+}$-ATPase on $\mathrm{d} 35$, and tended to decrease the 35 , significantly reduced serum GLU concentration on $\mathrm{d} 35$

Table 6. Effect of dietary L-carnitine supplementation on serum biochemical parameters

\begin{tabular}{|c|c|c|c|c|c|c|}
\hline $\begin{array}{l}\text { L-carnitine } \\
(\mathrm{mg} / \mathrm{kg})\end{array}$ & $\begin{array}{c}\mathrm{GLU} \\
\mathrm{mmol} / \mathrm{L}\end{array}$ & $\begin{array}{l}\mathrm{TP} \\
\mathrm{g} / \mathrm{L}\end{array}$ & $\begin{array}{c}\text { ALB } \\
g / L\end{array}$ & $\begin{array}{c}\text { GLO } \\
\text { g/L }\end{array}$ & $\begin{array}{c}\mathrm{TG} \\
\mathrm{mmol} / \mathrm{L}\end{array}$ & $\begin{array}{c}\mathrm{UA} \\
\mathrm{mg} / \mathrm{L}\end{array}$ \\
\hline \multicolumn{7}{|l|}{ D 21} \\
\hline 0 & 14.1 & 29.6 & 16.1 & 13.6 & 0.28 & 91.2 \\
\hline 100 & 14.2 & 28.9 & 15.6 & 13.0 & 0.28 & 79.1 \\
\hline Pool SEM & 0.099 & 0.442 & 0.161 & 0.345 & 0.007 & 3.15 \\
\hline p-value & NS & NS & NS & NS & NS & NS \\
\hline \multicolumn{7}{|l|}{ D 28} \\
\hline 0 & 13.7 & 30.6 & 17.1 & 13.7 & $0.47 * *$ & $90.4 *$ \\
\hline 100 & 13.5 & 30.3 & 16.9 & 13.4 & 0.25 & 71.9 \\
\hline Pool SEM & 0.185 & 0.383 & 0.218 & 0.262 & 0.035 & 4.09 \\
\hline p-value & NS & NS & NS & NS & 0.000 & 0.017 \\
\hline \multicolumn{7}{|l|}{ D 35} \\
\hline 0 & $14.3 * *$ & 40.0 & 18.6 & 21.0 & $0.49 *$ & $67.5 * *$ \\
\hline 100 & 13.4 & 39.4 & 18.6 & 20.7 & 0.25 & 54.0 \\
\hline Pool SEM & 0.144 & 0.409 & 0.124 & 0.303 & 0.055 & 2.70 \\
\hline p-value & 0.000 & NS & NS & NS & 0.012 & 0.000 \\
\hline \multicolumn{7}{|l|}{ D 42} \\
\hline 0 & $13.4 * *$ & 37.2 & 18.8 & 20.2 & 0.14 & $95.3 * *$ \\
\hline 100 & 12.4 & $41.5 *$ & 18.3 & $22.5 *$ & 0.14 & 68.3 \\
\hline Pool SEM & 0.197 & 0.964 & 0.346 & 0.572 & 0.007 & 5.25 \\
\hline p-value & 0.005 & 0.020 & NS & 0.042 & NS & 0.006 \\
\hline
\end{tabular}

GLU $=$ Glucose, $\mathrm{TP}=$ Total protein, $\mathrm{ALB}=$ Albumin, $\mathrm{GLO}=$ Globulins, $\mathrm{TG}=$ Triglyceride, $\mathrm{UA}=$ Uric acid.

NS $=$ Not significant, $* \mathrm{p}<0.05$ and $* * \mathrm{p}<0.01$ 
and 42, and significantly increased serum TP and GLO concentration on $\mathrm{d}$ 42. L-carnitine supplementation significantly reduced serum UA concentration on d 28, 35 and 42 .

\section{DISCUSSION}

Rabie et al. (1997) noticed improved growth rate, better food efficiency in broilers supplemented with L-carnitine supplementation. Khoshkhoo et al. (2006) found L-carnitine could significantly improve body weight gain only in 35 to $49 \mathrm{~d}$ old, but no effect in earlier ages. Hossininezhad et al. (2011) reported that feed conversion ratio was significantly decreased in total period by dietary L-carnitine supplementation. In contrast, Barker and Sell (1994), Leibetseder (1995) and Kidd et al. (2009) failed to observe any effects of L-carnitine supplementation on broiler performance. Zhang et al. (2010) reported that addition of ALC resulted in lower (linear effect, $\mathrm{p}<0.05$ ) ADG and AFI. The current study observed the effect of L-catnitine supplementation on broiler performance was not significant. However, this result does not mean that L-carnitine supplementation cannot have beneficial effects in other circumstances. Owen et al. (1996) reported differences in dosage level of L-carnitine, and physiological status of the animals may be responsible for the discrepancies between published studies. In addition, it is generally assumed that exogenous L-carnitine supplementation is only beneficial in the case of metabolic burdens such as cold or exercise. Geng et al. (2004) reported that dietary L-carnitine supplementation can increase broiler ascites-resistance and significantly reduce the mortality due to ascites. This study also found that the mortality due to ascites was significantly reduced by L-carnitine supplementation under a low temperature environment.

The broilers with ascites had lower body weight, but higher LUI, HI and AHI, which resulted in organs swelling and right heart hypertrophy (Cawthon et al., 2001; Luger et al., 2003; Özkan et al., 2006; Mohammadpour, 2007). Many studies take AHI $>0.27$ to 0.30 as a method of judging right ventricular hypertrophy and pulmonary hypertension that may result in ascites occurrence (Zerehdaran et al., 2006). This study found that dietary L-carnitine supplementation significantly decreased HI and AHI on d 21, LUI on d 35, and LI on d 42, which suggested that L-carnitine can reduce organ index of broiler reared under a low-temperature environment, thus increasing ascites-resistance.

Peroxidative damage and high oxidative stress caused by free radicals are considered to play an important role in the pathogenesis of ascites (Squires and Summers, 1993; Bottje et al., 1995). As L-carnitine (ester) is known to have free radical scavenging properties (Packer et al., 1991), it might also contribute to a beneficial effect on ascites occurrence. Geng et al. (2004) reported that dietary L-carnitine supplementation significantly increased liver T-SOD activity, and decreased MDA level. The result of present study showed that dietary L-carnitine supplementation significantly reduced MDA concentration of heart on d 21 and 35, and significantly increased T-SOD and GSH-Px activity of heart on d 21 and 42, and significantly reduced the mortality due to ascites. Therefore, L-carnitine might reinforce the antioxidant pool, protect myocardial energy production, and, as a result, reduce the incidence of ascites.

Buyse et al. (2001) reported L-carnitine supplementation significantly reduced plasma glucose concentration on $\mathrm{d} 17$. The current result also indicated that dietary L-carnitine supplementation significantly reduced serum glucose level on d 35 and 42. Feller and Rudman (1988) reported that L-carnitine can buffer the acetyl$\mathrm{CoA} / \mathrm{CoA}$ ratio, thus preventing the negative feedback of high acetyl-CoA level on PDH activity. As a consequence, the breakdown of glucose can proceed, leading to enhanced glucose utilization and hence lower plasma glucose level. Buyse et al. (2001) reported that both a low-temperature program and L-carnitine supplementation increased circulating plasma triiodothyronine $\left(\mathrm{T}_{3}\right)$ concentration, which indicated an increased oxidative metabolism and, hence, improved metabolic readiness. The current study indicated that L-carnitine supplementation significantly enhanced liver SDH, $\mathrm{MDH}$ and $\mathrm{Na}^{+}-\mathrm{K}^{+}$-ATPase activity on d 28, which suggests L-carnitine can improve mitochondrial function to produce more ATP for hepatocyte energy supplies. Therefore, L-carnitine may enhance glucose utilization and reduce serum glucose level through buffering the acetyl-CoA/CoA ratio, increasing circulating plasma T3 level, and enhancing mitochondrial enzyme activity involved in tricarboxylic acid cycle.

Daneshyar et al. (2009) reported that fasting blood GLU of cold-temperature treated birds at wk 4 and wk 6 was greater $(\mathrm{p} \leq 0.05)$ than normal-temperature treated birds, which suggested that gluconeogenesis was increased in ascites-susceptible chickens. Yersin et al. (1992) and Enkvetchakul et al. (1993) observed a decrease of serum albumin concentration with ascites. Biswas et al. (1995) reported decreased serum protein in fast-growing chickens experiencing ascites. It is suggested that deaminated amino acids might contribute to the high rate of gluconeogenesis found in hepatocytes of broilers with ascites. Kheiri et al. (2011) reported that L-carnitine $(60 \mathrm{mg} / \mathrm{kg})$ significantly increased blood GLU level, but $120 \mathrm{mg} / \mathrm{kg}$ significantly decreased blood GLU level. The result of this study found that dietary L-carnitine supplementation significantly decreased blood GLU concentration on d 35 and 42, significantly increased serum total protein and globulin on $\mathrm{d}$ 42 , and significantly reduced serum UA content on d 28, 35 
and 42. This suggests that L-carnitine can increase glucose oxidative metabolism, and decrease the rate of hepatic gluconeogenesis.

Arslan et al. (2003) reported that L-carnitine had a trend to decrease serum cholesterol and TG. Zhang et al. (2010) reported that serum total cholesterol and TG level were significantly decreased with increased acetyl-L-carnitine (ALC) in diets. Kheiri et al. (2011) reported that L-carnitine $(60 \mathrm{mg} / \mathrm{kg})$ significantly reduced TG, but increased serum cholesterol level. The current study also indicated that L-carnitine supplementation significantly reduced serum TG on d 28 and 35, which is in accordance with the antihyper-triglyceridaemic effect of L-carnitine in cachexia and septic shock (Winter et al., 1995). However, Lien and Horng (2001) and Khoshkhoo et al. (2006) found no significant effects on serum cholesterol and TG level. Therefore, dietary L-carnitine supplementation may involved the regulation of energy production in liver tissue during ascites developing by affecting lipid and glucose metabolism.

\section{CONCLUSION}

In conclusion, dietary supplemented with L-carnitine can reduce organ index, RBC and HCT to decrease ascitessusceptibility. It can also enhance antioxidative ability of the heart to protect myocardial cells from lipid peroxidation damage and enhance the activity of liver SDH, MDH and $\mathrm{Na}^{+}-\mathrm{K}^{+}$-ATPase to improve glucose oxidative metabolism. Therefore, it is suggested that L-carnitine can serve as a potential regulatory agent to reduce ascites susceptibility and mortality.

\section{ACKNOWLEDGEMENTS}

We thank Professor Austin H. Cantor from University of Kentucky for critical reading of the manuscript. Lonza (China) investment Co., LTD. is also appreciated for the supply of L-carnitine.

The work was supported by Beijing Natural Science Foundation (Project NO.: 6111002) and the Ear-marked Fund for China Agriculture Research System.

\section{REFERENCES}

Arab, H. A., R. Jamshidi, A. Rassouli, G. Shams and M. H. Hassanzadeh. 2006. Generation of hydroxyl radicals during ascites experimentally induced in broilers. Br. Poult. Sci. 47: 216-222.

Arslan, C., M. Citil and M. Saatci. 2003. Effects of L-carnitine administration on growth performance, carcass traits, blood serum parameters and abdominal fatty acid composition of ducks. Arch. Anim. Nutr. 57:381-388.

Baghbanzadeh, A. and E. Decuypere. 2008. Ascites syndrome in broilers: physiological and nutritional perspectives. Avian Pathol. 37:117-126.

Balog, J. M. 2003. Ascites syndrome (pulmonary hypertension syndrome) in broiler chickens: are we seeing the light at the end of the tunnel? Avian Poult. Biol. Rev. 14:99-126.

Barker, D. L. and J. L. Sell. 1994. Dietary carnitine did not influence performance and carcass composition of broiler chickens and young turkeys fed low- or high-fat diets. Poult. Sci. 73:281-287.

Biswas, N. K., M. R. Dalapati and M. K. Bhowmik. 1995. Ascites syndrome in broiler chickens: Observations on certain biochemical and pathological changes. Indian J. Anim. Sci. 65:1068-1072.

Bottje, W. G. and R. F. Wideman. 1995. Potential role of free radicals in the etiology of pulmonary hypertension syndrome. Poult. Avian Biol. Rev. 6:211-231.

Bottje, W., G. Erf, T. Bersi, S. Wang, D. Barnes, and K. Beers. 1997. Effect of dietary DL- $\alpha$-tocopherol on tissue and $\alpha$ - and $\gamma$-tocopherol and pulmonary hypertension syndrome (ascites) in broilers. Poult. Sci. 76:1506-1512.

Buyse, J., G. P. Janssens and E. Decuypere. 2001. The effects of dietary L-carnitine supplementation on the performance, organ weights and circulating hormone and metabolite concentrations of broiler chickens reared under a normal or low temperature schedule. Br. Poult. Sci. 42:230-241.

Cawthon, D., K. Beers and W. G. Bottje. 2001. Electron transport chain defect and inefficient respiration may underlie pulmonary hypertension syndrome (ascites) associated mitochondrial dysfunction in broilers. Poult Sci. 80:474-484.

Daneshyar, M., H. Kermanshahi and A. Golian. 2009. Changes of biochemical parameters and enzyme activities in broiler chickens with cold-induced ascites. Poult. Sci. 88:106-110.

Diaz-Cruz, A., C. Nava, R. Villanueva, M. Serret, R. Guinzberg and E. Pina. 1996. Hepatic and cardiac oxidative stress and other metabolic changes in broilers with the ascites syndrome. Poult. Sci. 75:900-903.

Enkvetchakul, B., W. Bottje, N. Anthony, R. Moore and W. Huff. 1993. Compromised antioxidant status associated with ascites in broilers. Poult. Sci. 72:2272-2280.

Feller, A. G. and D. Rudman. 1988. Role of carnitine in human nutrition. J. Nutr. 118:541-547.

Geng, A. L., Y. M. Guo and J. M. Yuan. 2004. Effects of dietary Lcarnitine and coenzyme Q10 supplementation on Performance and ascites mortality of broilers. Arch. Anim. Nutr. 58:473-482.

Hossininezhad, M. M., M. Irani and A. Seidavi. 2011. Dietary effects of L-carnitine supplement on performance and blood parameters of broiler chickens. J. Food Agric. Environ. 9:475481.

Julian, R. J. 1993. Ascites in poultry. Avian Pathol. 22:419-454.

Kheiri, F. J. Pourreza, Y. Ebrahimnezhad, K. Nazeradl and S. M. A. J. Haji-abadi. 2011. Effects of supplemental ractopamine and L-carnitine on growth performance, blood biochemical parameters and carcass traits of male broiler chicks. Afr. J. Biotechnol. 10:15450-15455.

Khoshkhoo, P. H., G. A. Azad, N. Ila, F. Moayer and H. D. Nayeri. 2006. Effect of dietary L-carnitine supplementation on overall performance, carcass traits, serum components and immune response in broiler chicken. EPC 2006-12th European Poultry Conference, Verona, Italy, p. 167. 
Kidd, M. T., J. Gilbert, A. Corzo, C. Page, W. S. Virden and J. C. Woodworth. 2009. Dietary L-carnitine influences broiler thigh yield. Asian-Aust. J. Anim. Sci. 22:681- 685.

Leibetseder, J. 1995. Effects of L-carnitine in poultry. Arch Tierernahr. 48:97-108.

Lien, T. F. and Y. M. Horng. 2001. The effect of supplementary dietary L-carnitine on the growth performance, serum components, carcass traits and enzyme activities in relation to fatty acid $\beta$-oxidation of broiler chickens. Br. Poult. Sci. 42 : 92-95.

Lorenzoni, A. G. and C. A. Ruiz-Feria. 2006. Effects of vitamin E and L-arginine on cardiopulmonary function and ascites parameters in broiler chickens reared under subnormal temperatures. Poult. Sci. 85:2241-2250.

Luger, D., D. Shinder, D. Wolfenson and S. Yahav. 2003. Erythropoiesis regulation during the development of ascites syndrome in broiler chickens: A possible role of corticosterone. J. Anim. Sci. 81:784-790.

Maxwell, M. H. and G. W. Robertson. 1997. World broiler ascites survey 1996. Poult. Int. 36:16-30.

Mohammadpour, A. A. 2007. Comparative histomorphological study of heart in healthy and ascites broiler chickens in Shahrekord district, Iran. Vet. Res. Commun. 31:461-465.

NRC. 1994. Nutrition requirements of poultry. 9th edn. Natl. Acad. Sci., Washington DC, USA.

Olkowski, A. A., S. Nain, C. Wojnarowicz, B. Laarveld, J. Alcorn and B. B. Ling. 2007. Comparative study of myocardial high energy phosphate substrate content in slow and fast growing chicken and in chickens with heart failure and ascites. Comp. Biochem. Physiol. A Mol. Integr. Physiol. 148:230-238.

Özkan, S., I. Plavnik and S. Yahav. 2006. Effects of early feed restriction on performance and ascites development in broiler chickens subsequently raised at low ambient temperature. J. Appl. Poult. Res. 15:9-19.

Owen, K. Q., J. L. Nelssen, R. D. Goodband, T. L.Weeden and S. A. Blum. 1996. Effect of L-carnitine and soy-bean oil on growth performance and body composition of early-weaned pigs. J. Anim. Sci. 74:1612-1619.

Packer, L., M. Valenza, E. Serbinosa, P. Starke-Reed, K. Frost and V. Kagan. 1991. Free radical scavenging is involved in the protective effects of L-propionyl-carnitine against ischemia reperfusion injury of the heart. Arch. Biochem. Biophys. 288:533-537.

Rabie, M. H., M. Szilágyi, T. Gippert, E. Votisky and D. Gerendai. 1997. Influence of dietary L-carnitine on performance and carcass quality of broiler chickens. Acta. Biol. Hung. 48:241252 .
SPSS. 2008. SPSS version 16.0 for Windows. SPSS Inc.,Chicago, III.

Squires, E. J. and L. D. Summers. 1993. A consideration of comparative metabolic aspects of the aetiology of sudden death syndrome and ascites in broilers. Br. Vet. J. 149:285-294.

Stolz, J. L., L. M. Rosenbaum, D. Jeong and T. W. Odom. 1992. Ascites syndrome, mortality and cardiological responses of broiler chickens subjected to cold exposure. Poult. Sci. 71(Suppl 1): 4(Abstr.).

Tan, G. Y., L. Yang, Y. Q. Fu, J. H. Feng and M. H. Zhang. 2010. Effects of different acute high ambient temperatures on function of hepatic mitochondrial respiration, antioxidative enzymes, and oxidative injury in broiler chickens. Poult. Sci. 89:115-122.

Tan, X., W. D. Sun, J. C. Li, J. Q. Pan, Y. J. Liu, J. Y. Wang and X. L. Wang. 2007. L-Arginine prevents reduced expression of endothelial nitric oxide synthetase (NOS) in pulmonary arterioles of broilers exposed to cool temperatures. Vet. J. 173:151-157.

Villar-Patino, G., A. Diaz-Cruz, E. Avila-Gonzalez, R. Guinzberg, J. L. Pablos and E. Pina. 2002. Effects of dietary supplementation with vitamin $\mathrm{C}$ or vitamin $\mathrm{E}$ on cardiac lipid peroxidation and growth performance in broilers at risk of developing ascites syndrome. Am. J. Vet. Res. 63:673-676.

Wang, Y. W., Y. M. Guo, D. Liu, Y. Yang and D. Ning. 2012. Changes of biochemical parameters and proteomics in livers of broiler chickens with cold-induced ascites. Poultry Science Association Annual Meeting, Athens, Georgia, America, p. 149. Winter, B. K., G. Fiskum and L. L. Gallo. 1995. Effects of Lcarnitine on serum triglyceride and cytokine levels in rat models of cachexia and septic shock. Br. J. Cancer. 72:11731179.

Yersin, A. G., W. E. Huff, L. F. Kubena, M. A. Elissalde, R. B. Harvey, D. A. Witzel and L. E. Giroir. 1992. Changes in hematological, blood gas and serum biochemical variables in broilers during exposure to stimulated high altitude. Avian Dis. 36:189-197.

Zerehdaran, S., E. M. van Grevehof, E. H. van der Waaij and H. Bovenhuis. 2006. A bivariate mixture model analysis of body weight and ascites trait in broilers. Poult. Sci. 85:32-38.

Zhang, Y, Q. G. Ma, X. M. Bai, L. H. Zhao, Q. Wang, C. Ji, L. T. Liu and H. C Yin. 2010. Effects of dietary acetyl-L-carnitine on meat quality and lipid metabolism in arbor acres broilers. Asian-Aust. J. Anim. Sci. 23:1639-1644. 